\title{
Kommuniserbar sykdom
}

Å være lege er å kommunisere. Mesteparten av tiden i pasientkonsultasjonen brukes til informasjonsoverføring - fra pasienten om livet, plagene og egen forståelse av dem, fra legen råd, trøst og ganske ofte beroligelse. «Det er ikke farlig,» sier jeg når jeg sitter i allmennlegestolen. «Dette trenger du ikke bekymre deg for. Ikke slutt med den medisinen.» Men selv om pasienten har mottatt og forstått min informasjon på vei ut av døren, er det ikke godt å si hvor stor gjennomslagskraften er. Noen minutters informasjon fra legen konkurrerer med kakofonien om helse, kropp og sykdom som min pasient får inn via smarttelefon, $\mathrm{PC}, \mathrm{TV}$ og papiraviser.

Communicable diseases tilsvarer på norsk smittsomme sykdommer. Den direkte oversettelsen kommuniserbare sykdommer anskueliggjør et viktig spørsmål: Kan kommunikasjon skape eller viderebringe sykdom?

Detaljert mediedekning av enkeltselvmord synes å gi økt risiko for selvmord hos andre (1). Mediene anerkjenner at de har et ansvar når det gjelder selvmordsforebygging. Vær varsom-plakaten inneholder derfor en egen paragraf om å være varsom ved omtale av selvmord og selvmordsforsøk (2). Men også andre og mindre dramatiske helseeffekter enn selvmord hevdes å oppstå som følge av medieomtale.

I 1999 skrev professor i sosialmedisin Per Fugelli kronikken Dagblad-sykdommer - hederlig nok trykt i selvsamme avis (3). Her raser han over tabloidoverskrifter som Drikkevannet kan gi kreft og Giftalarm i barnerommet og hevder at slik skrekk-og-gru-journalistikk kan skade folks helse og sykdomskultur på tre måter: Man kan bli syk av engstelse, immun mot fornuftig helseopplysning og skjevinformert om årsakene til helse og sykdom.

«Borrelia smitter gjennom Internett,» sier smittevernlege Preben Aavitsland (4). «Epidemien med «kronisk borreliose» drives fram av privatklinikker, pasientaktivister, massemediene og enkelte politikere,» mener han. Forfatter og blogger Gunnar Tjomlid hevder at noceboeffekten smitter gjennom mediene (5). Og nylig spurte Samdal \& Meland her i Tidsskriftet om det er overvekt eller vektfokus som er helseskadelig (6). De argumenterer for at farene ved overvekt er betydelig overdrevet og at blant annet mediene driver en helseskadelig stigmatisering av overvektige og fete.

Felles for alle disse er at de mener visse typer medieoppslag har en negativ effekt på helsen. Felles er også at de ikke tydelig kan dokumentere en slik årsakssammenheng. Mediene er en del av våre naturlige omgivelser, og det er umulig å randomisere folk til medieeksponering eller ikke-medieeksponering på en realistisk måte. Regisserte helsekampanjer i mediene synes å ha en positiv effekt på folks atferd (7). Verre er det altså å påvise helseeffektene av redaksjonelt medieinnhold. Vi vet at mye av helsejournalistikken er ukritisk og unøyaktig (8), at det kan påvises en tidssammenheng mellom medieoppslag om en fiktiv tilstand og befolkningens tro på at de har tilstanden (9), og at overvekt assosieres med skyld og skam i avisartikler (10). Men vi vil dessverre aldri få vite hvor mange ungdommer som utvikler et negativt kroppsbilde, depresjon og spiseforstyrrelse av TVNorges nye slankeserie The biggest loser eller antallet nordmenn som blir utsatt for medikamentbivirkninger og feildiagnostisering som følge av Dagbladets borreliosejournalistikk.

Annerledes er det for redaksjonene - de har full oversikt over effekten av sine oppslag og programkonsepter. Forskjellen er at de måler effekten i salgstall, seeroppslutning og klikk. Den som håper at massemediene skal oppføre seg som om de var en del av helsevesenet, er dømt til å bli skuffet.

Er mediene støttende eller saboterende for helsen? spør The Lancet på lederplass (11). Det beste svaret på det umulige spørsmålet er ja. Mediene er en uvurderlig støttespiller når det gjelder å informere og myndiggjøre allmennheten i helsespørsmål. Lancet-redaktøren mener journalister med gode intensjoner lett kan havne i en skvis mellom overdrevent kritisk helsepersonell og sensasjonshungrige lesere.

Samtidig er det god grunn til å tro at visse deler av journalistikken forårsaker unødvendig engstelse, overbehandling, urealistiske forventninger og uhelse. Selv om disse sammenhengene er svakere dokumentert enn hva tilfellet er for smitteeffekten av selvmordsomtale, kan det også her være verdt å gå til Vær varsom-plakaten: «Det er pressens oppgave å beskytte enkeltmennesker og grupper mot overgrep eller forsømmelser.» Og, ikke minst: «Det er pressens plikt å sette et kritisk søkelys på hvordan mediene selv fyller sin samfunnsrolle» (2).

Inntil videre er mitt råd til en del av pasientene: «Det er ikke sikkert det er så lurt å google dette.» Det gir meg en viss betryggelse at de smiler megetsigende tilbake.

\section{Litteratur}

1. Stack S. Media coverage as a risk factor in suicide. J Epidemiol Community Health 2003; 57: 238-40.

2. Norsk presseforbund. Vær varsom-plakaten. http://presse.no/pfu/etiske-regler/ vaer-varsom-plakaten/ (27.1.2015)

3. Fugelli P. Dagblad-sykdommer. Kronikk. Dagbladet 23.1.1999.

4. Aavitsland P. Smitte med «kronisk borreliose» på Internett. http://epidemi.as/ $? \mathrm{p}=350(27.1 .2015)$

5. Tjomlid G. Saksynt. http://tjomlid.com/2014/09/15/folkets-stralevern-gjor-folkstralesyke/ (27.1.2015).

6. Samdal GB, Meland E. Er det overvekt eller vektfokus som er helseskadelig? Tidsskr Nor Legeforen 2014; 134: 2247-8.

7. Wakefield MA, Loken B, Hornik RC. Use of mass media campaigns to change health behaviour. Lancet 2010; 376: 1261-71

8. Høye S, Hjortdahl P. «Ny vidunderpille!»-hva skriver norske aviser om nye legemidler? Tidsskr Nor Lægeforen 2002; 122: 1671-6.

9. Chapman S, St. George A, Waller K et al. The pattern of complaints about Australian wind farms does not match the establishment and distribution of turbines: support for the psychogenic, 'communicated disease' hypothesis. PLOS ONE 2013; 8: e76584

10. Malterud K, Ulriksen K. «Norwegians fear fatness more than anything else» a qualitative study of normative newspaper messages on obesity and health Patient Educ Couns 2010; 81: 47-52.

11. Does the media support or sabotage health? Lancet 2009; 373: 604. 